\title{
Upper Cretaceous Limestones as Stone Resources for the Monuments of Oviedo (Asturias, NW of Spain): Petrographic Variability and Stratigraphic Origin
}

\author{
B. González-Fernández ${ }^{1}$ (1) F. J. Alonso ${ }^{2} \cdot$ L. Valdeón ${ }^{3} \cdot$ L. Pando ${ }^{2}$
}

Received: 13 July 2021 / Accepted: 9 February 2022 / Published online: 21 February 2022

(c) The Author(s) 2022

\begin{abstract}
This study offers an analysis of the petrographic variability and the stratigraphic origin of the rocks used as building stones in the vast majority of the historical monuments of Oviedo, including UNESCO World Heritage Sites. More than a hundred samples of Upper Cretaceous stone were obtained from monuments and outcrops. Based on petrographic characteristics, a macroscopic scale classification was established, and two lithotypes were identified, Piedramuelle and La Granda. Further varieties were differentiated at a microscopic scale: five in the first lithotype and two in the second one. Regarding stratigraphic origin, both rock types come from the Upper Cretaceous San Lázaro and Oviedo Formations. The building stones were mostly extracted from quarries located in the surroundings of the city and, in some cases, within the urban area. The lithotype used in monuments built up to the eighteenth century is Piedramuelle, while La Granda dominates in buildings erected during the seventeenth and eighteenth centuries.
\end{abstract}

Keywords Oviedo $\cdot$ Historical monuments $\cdot$ Building stones $\cdot$ Cretaceous $\cdot$ Petrography $\cdot$ Lithotypes

\section{Introduction}

Typically, architectural heritage buildings are built with natural stone. The facades of historic buildings, as boundary elements of public architectural spaces, have an influence on the atmosphere and life of cities (Durante et al. 2018; Mao et al. 2020) and its tourist worth (Fio and Maricic 2020). Consequently, adequate maintenance that guarantees a pleasing appearance of building facades can provide greater benefits than the cost of the maintenance.

A profound knowledge of the characteristics and origin of the stone is fundamental in stone restoration and conservation works. Different studies have proved the interest

B. González-Fernández

mbeagf@uniovi.es

1 Department of Mining Exploitation and Prospecting, University of Oviedo, Independencia 13, 33004 Oviedo, Spain

2 Department of Geology, University of Oviedo, Jesús Arias de Velasco s/n, 33005 Oviedo, Spain

3 GEA, asesoría geológica, Polígono de Silvota, 39192 Llanera, Spain in identifying the stone quarries that originally provided the architectural and sculptural materials (Martínez-Torres 2007; Fort et al. 2013; Corbí et al. 2019; Gökçe et al. 2020; Shekofteh et al. 2020) and the importance of petrographic analysis to trace the origin of the stone and infer distribution patterns (Dreesen and Dusar 2004; Malfilatre et al. 2012; López-Plaza et al. 2016; Barroso et al. 2020; Merino et al. 2020).

Stone material undergoes alteration processes when exposed to the elements (Martínez-Martínez et al. 2017; Damas Mollá et al. 2018; Sitzia et al. 2021), and if the damage is significant, the stone must be replaced to prevent further deterioration and the ruin of the building. In these cases, it is convenient to know the origin of the material: the geographical and geological location of the lithotypes, the exact formations, or even outcrops of origin (Fronteau et al. 2010; Bone 2016; Carter et al. 2017; Ajanaf et al. 2020). This information will make it possible to locate a stone that is similar to the original in characteristics and properties and, so, in behavior (Bugini and Folli 2008; De Kock et al. 2015; Zoghlami et al. 2017; Anania et al. 2012; Forestieria and Álvarez de Buergo 2019), and to find the most suitable material to replace ashlars or other construction elements in heritage restoration works. 
Some authors deal with sustainability in the use of geological resources and highlight the interest of local stones, together with reusing/recycling waste materials, as a source

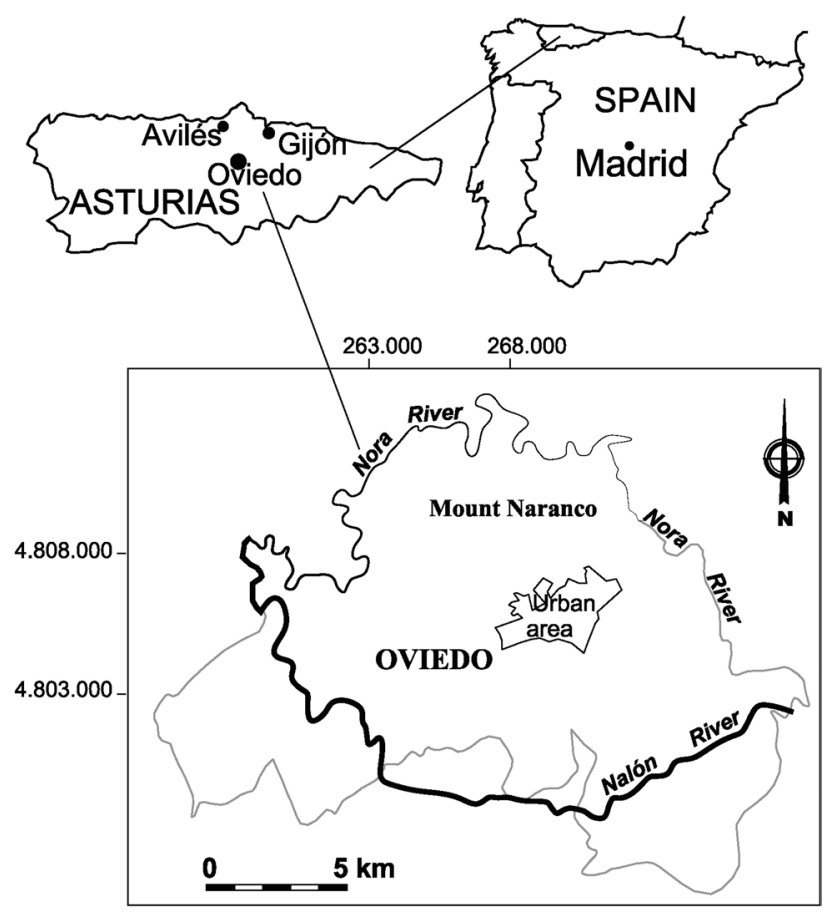

Fig. 1 Location of the study area of supply of raw materials for construction, in line with the EU policy in its Europe 2020 strategy (Dino et al. 2018).

The monumental heritage of the city of Oviedo (Fig. 1) is built with the Upper Cretaceous limestones extracted from under the city. Among the Cretaceous rocks that underlie the city and its surroundings, different types of limestone can be distinguished according to their stratigraphic position and petrographic characteristics. The medieval town settled on top of these materials, and given their easy availability, they have been used for building purposes in and around the urban area, ever since.

Numerous ecclesiastical buildings, palaces and civil infrastructures have been erected with these Upper Cretaceous rocks in and around the Asturian capital (Fig. 2). The oldest monuments preserved in Oviedo are, by order of age, the churches of San Julián de los Prados and San Miguel de Lillo and the palatial building of Santa María del Naranco, all of them of the high medieval artistic style known as Asturian pre-Romanesque (ninth century). Another notable construction in the city is the Cathedral of San Salvador de Oviedo, built between the thirteenth and eighteenth centuries, with a variety of architectural styles, from Gothic to Baroque, although it also includes older structures, such as the Cámara Santa (Holy Chamber), from the pre-Romanesque, and Old Tower of the Cathedral, from the Romanesque (twelfth century). The mentioned pre-Romanesque monuments, including the Cámara Santa, were declared World Heritage Sites by UNESCO, in the years 1985 and 1998, and are part of the so-called
Fig. 2 Relevant monuments built with Cretaceous stone: Cathedral of San Salvador de Oviedo (A), Santa María del Naranco (B) and palace of Duque del Parque (C) with Piedramuelle lithotype. Facade of the cathedral cloister (D), church of San Isidoro (E) and convent of Santa Clara $(\mathbf{F})$ with La Granda lithotype

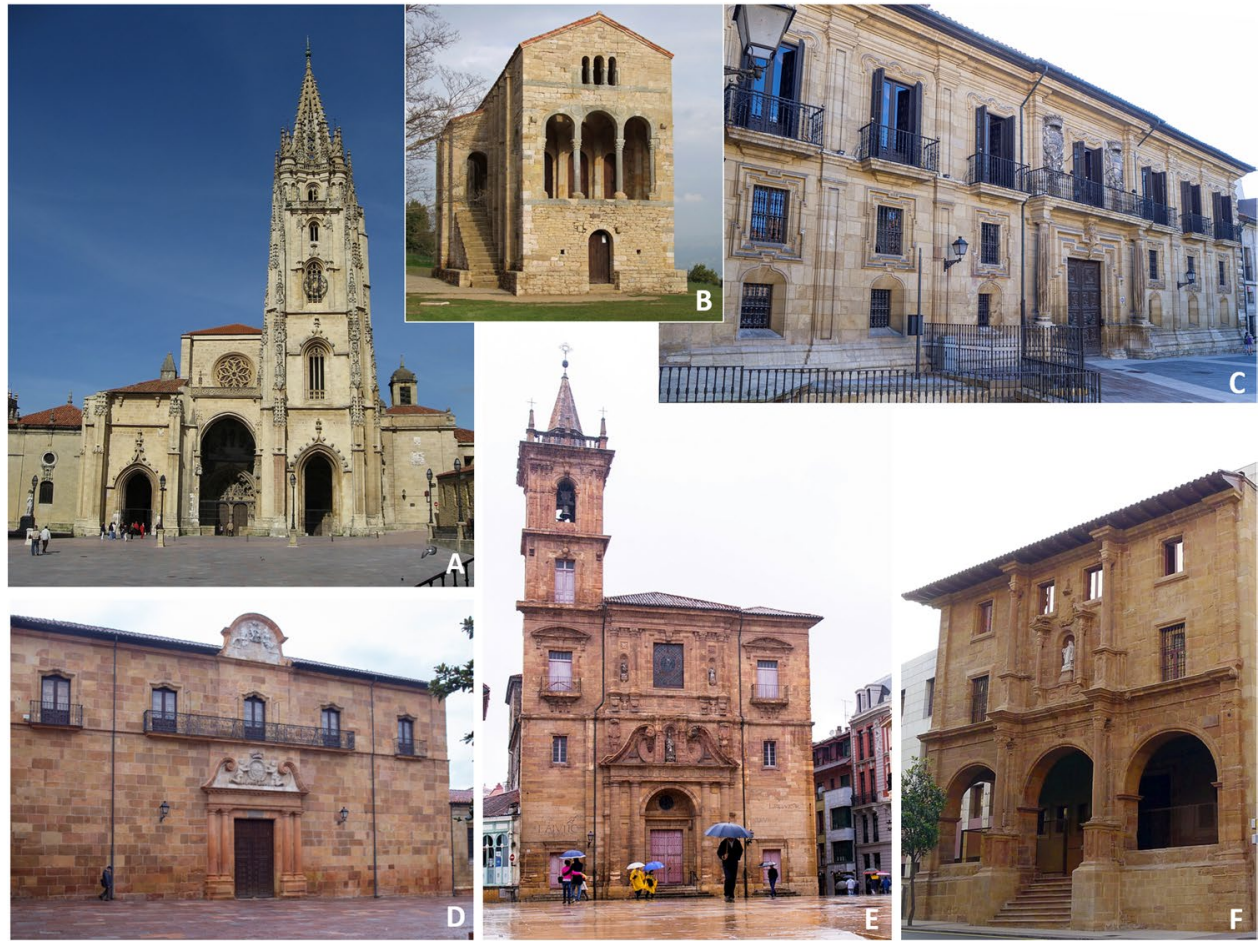


"Monuments of Oviedo and the Kingdom of Asturias." A set of other constructions could be listed here that have also been declared Objects of Cultural Interest (BIC), the highest protection figure in the Spanish Historical Heritage Law. Thus, with limestones from the Upper Cretaceous, monasteries (San Vicente, Santa Clara), churches (San Tirso, San Isidoro, Santo Domingo), palaces (Camposagrado, Toreno, Valdecarzana, Velarde), noble houses, the Oviedo city wall, Los Pilares aqueduct, the old hospice, etc. have been built for over ten centuries and, so, cover a wide range of styles: pre-Romanesque, Romanesque, Gothic, Renaissance, Baroque and Neoclassical.

The century-long use of these rocks in the local architectural heritage has increased their importance as natural stone. Several authors have studied the petrographic types present in the fabric of specific monuments (Esbert et al. 1992a; Álvarez et al. 2004; Mateos et al. 2004) and their petrophysical characteristics in the laboratory (Alonso et al. 1999) and have identified two types or lithotypes called Piedramuelle and La Granda (Fig. 2). Petrography and physical properties are decisive factors in the analysis of stone alteration and conservation. The thorough knowledge of these properties is essential to interpret the causes and processes that act in the deterioration of the stone and to assess the required actions or the effectiveness of treatments for its conservation and maintenance (Esbert et al. 2008; Garcíadel-Cura et al. 2012; Vázquez et al. 2013; De Kock et al. 2017; Vázquez et al. 2018). In the monuments of Oviedo, studies have been carried out about stone deterioration diagnosis and damage (Esbert and Marcos 1983; Esbert et al. 1992b; Esbert et al. 1997; Ordaz et al. 2004; Alonso et al. 2007) and also about petrological monitoring during conservation interventions (Valdeón and Esbert 2000; Esbert et al. 2004: Valdeón et al. 2003; Rojo et al. 2006). Other studies addressed the exploration of old quarries that supplied the stone (Pando et al. 2011; Gutiérrez-Claverol et al. 2012).

Although the object of this research is the Cretaceous limestone, it should be noted that there is a third stone type, the Laspra dolomite of Paleogene age that has also been used as a dimension stone in the monuments of Oviedo. This stone is highly valued for its whitish tone and ease for carving, although, due to its high alterability in exterior environmental conditions, it was preferably destined for building interiors (Esbert et al. 1982; Esbert and Marcos 1983). Likewise, certain elements of Oviedo monuments were built with Quaternary carbonates, such as the travertine used in the vaults of several medieval buildings - for example in Santa María del Naranco - due to its low density great lightness (González-Fernández et al. 2010). Sandstone has also been used in monumental buildings, although it is only present in the fabric of Foncalada fountain (Mateos et al. 2004), in singular constructive elements of pre-Romanesque buildings, such as corbels or lintels (Álvarez et al. 2004), and in some remains of pre-existing, primitive structures reused within the walls of the cathedral (Valdeón 2004).

The objective of this research is to analyze the petrographic variability and the stratigraphic origin of the Upper Cretaceous limestones used as building stone in the geographical area of Oviedo. Based on the visual petrographic characteristics, a first macroscopic classification was established. Furthermore, within each lithotype, varieties were differentiated at the microscopic level. The origin of these petrographic varieties was also traced, and they were positioned on the lithostratigraphic succession of Asturian Cretaceous. Finally, the spatial and temporal relationship between the monuments and the quarries that provided the rocks used in their construction is analyzed.

\section{Geological Setting}

Oviedo is situated on a discordant Meso-Paleogene basin over a strongly deformed Paleozoic basement (Fig. 3a) that belongs to the Cantabrian Zone, the outermost sector of the Hesperian Massif (Julivert et al. 1972). The deformations produced during the Alpine compressive phase, with reactivation of Variscan structures (Pulgar et al. 1999), formed a basin with asymmetric syncline morphology with a southern flank slightly inclined towards the $\mathrm{N}$ and a more vertical northern flank (Fig. 3b). The main fracture network is determined by three subvertical fault systems with preferential orientations of NE-SW, NW-SE to NNO-SSE, and E-W (Gutiérrez-Claverol and Torres 1995).

The full Asturian Cretaceous series consists of ten lithostratigraphic units with a total thickness of about 600 $\mathrm{m}$, where siliciclastic and carbonate members alternate (González-Fernández et al. 2004). The terrigenous units, from bottom to top, are the Peñaferruz, Pola de Siero, El Caleyu, Latores and La Argañosa Formations; and the calcareous units comprise the Antromero, Ullaga, La Manjoya, San Lázaro and Oviedo Formations. The three basal units (Peñaferruz, Antromero and Pola de Siero), dated as Barremian-Aptian, are not present in the study area, where the outcrops mainly correspond to the three uppermost units, the San Lázaro, La Argañosa and Oviedo Formations, all of them from the Upper Cretaceous.

The San Lázaro Formation is composed of a set of predominantly carbonate materials subdivided into three members and has a total thickness of around $50 \mathrm{~m}$ in the urban area. The lower member is formed by an alternation of clays, marls, silts, sandstones, and limestones. The sedimentary environment of these materials corresponds to a shallow sub-littoral area within an open bay-lagoon system. The middle member is formed by nodulous, generally bioclastic, limestones; and the upper one by bioclastic, sometimes sandy, limestones. The limestones of both members 
Fig. 3 Geological map of the study area (A) and schematic geological section of the basin (B)

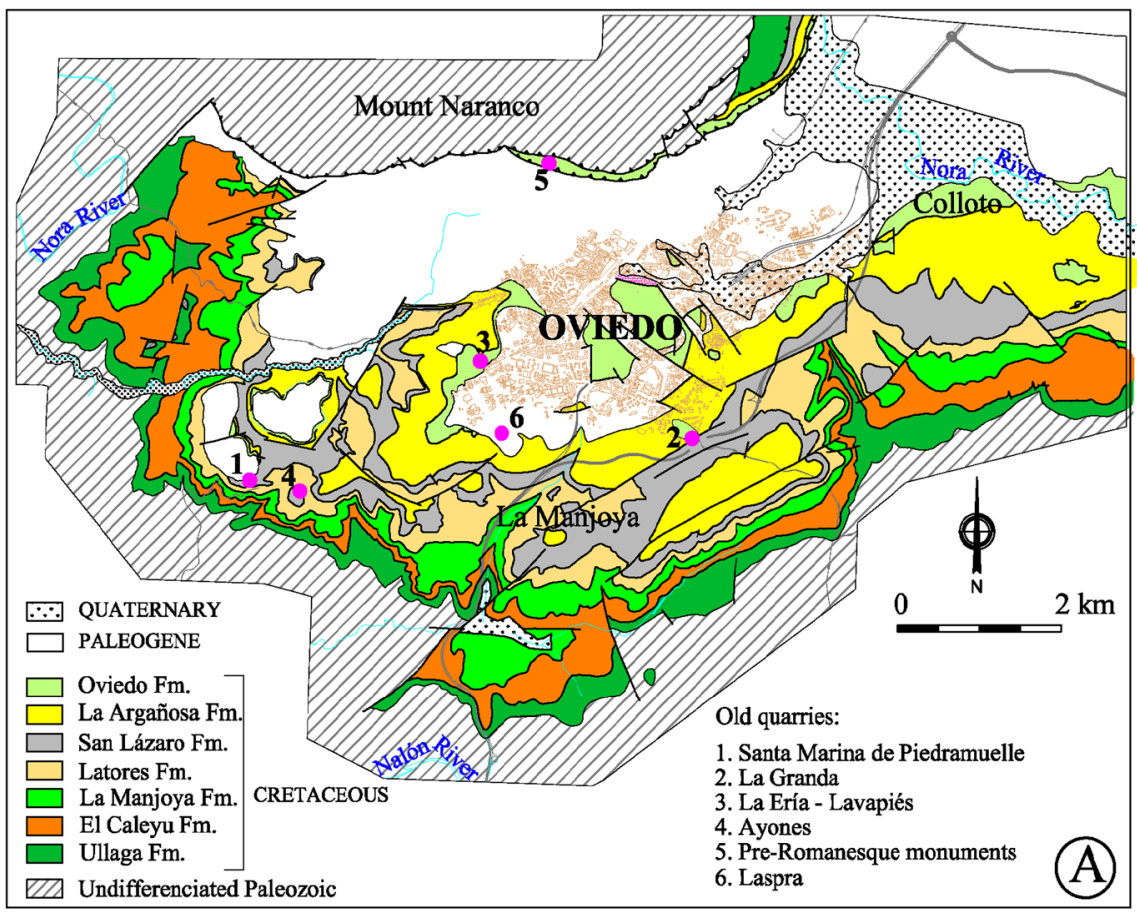

m.a.s.l.

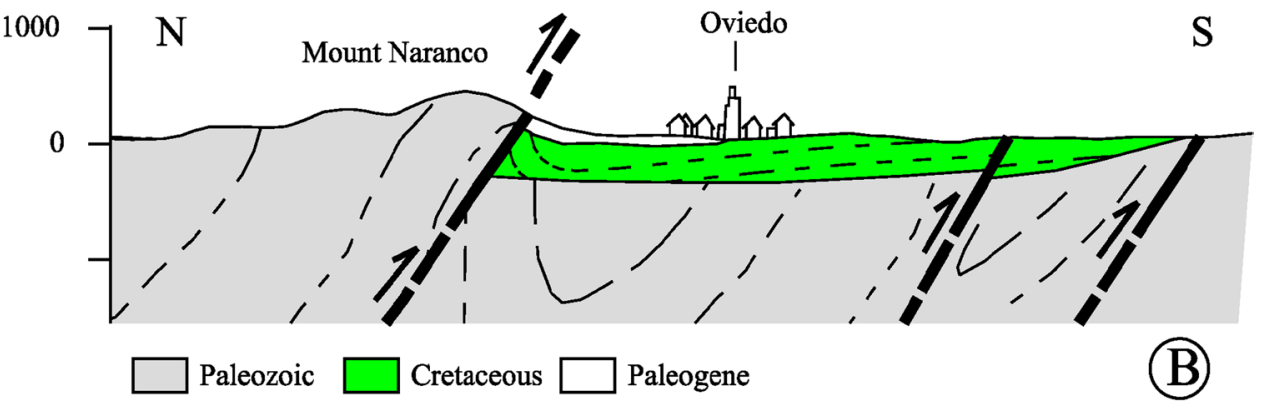

are usually karstified. Their deposition corresponds to the maximum transgressive phase of the Cretaceous of Asturias and was developed in a shallow platform environment. Its age is between the Upper Cenomanian and the LowerMiddle Turonian.

The La Argañosa Formation is composed of sands of varied grain size with intercalations of siliceous gravels, conglomerates or micro-conglomerates, as well as levels of silt and clay. This unit, which has been extracted in clay and sand pits, can reach a thickness of about $40 \mathrm{~m}$. Its deposition took place in a fluvial depositional environment within an episode of sea level decrease.

Finally, on the top, the Oviedo Formation comprises mainly bioclastic, sandy, and sometimes nodular limestones with some intercalations of calcareous sandstones. It is usually affected by karstification and weathering (Gutiérrez-Claverol et al. 2004, 2008). Its maximum thickness is about $40 \mathrm{~m}$, but in some areas, it disappears due to a paleo relief at the top of the Cretaceous series. Under the city, it does not usually exceed 10-15 m of thickness (Fernández-Álvarez and Pando 2019). The sedimentary environment corresponds to different zones within a tidal plain: open subtidal, shallow subtidal, and intertidal. Its age can be placed between the Coniacian and Santonian.

Over the Mesozoic units, a Paleogene fluvial-lacustrine cover lies in low-angle unconformity, characterized by very pronounced lateral facies changes, although with a general gain in siliciclastic materials towards the top. With a total thickness greater than $200 \mathrm{~m}$, the lower stretch of its three sub-units (Gutiérrez-Claverol and Torres 1995) contains carbonate levels from which the so-called Laspra stone comes. It outcrops at different points within and around the urban area of Oviedo. Finally, the Quaternary is represented by fluvial sediments, especially developed in the extreme $\mathrm{NE}$ of the city - with a thickness up to about $6 \mathrm{~m}$ - as well as colluvial deposits that cover the southern slope of Mount Naranco, and some travertine levels associated with springs that emerge from the carboniferous limestones. As is usual in an urban setting, the shallowest horizon is made 
up of anthropic landfills of different composition and origin (earthmoving works, dumping sites, etc.).

\section{Methodology}

Both laboratory and field data were used to identify the main petrographic types and their varieties. More than a hundred samples of Cretaceous stone were collected, around half of which came from architectural elements of the monuments (Fig. 4, Table 1). The other half was taken from different points of the urban nucleus and its surroundings where the Upper Cretaceous units outcrop (Fig. 4, Table 2) and also from a borehole of a previous research located northeast of Oviedo. Monument fabrics were inspected carefully in order to identify the employed lithotypes. Some outcrops were also thoroughly studied to identify visually the types of rock, paying close attention

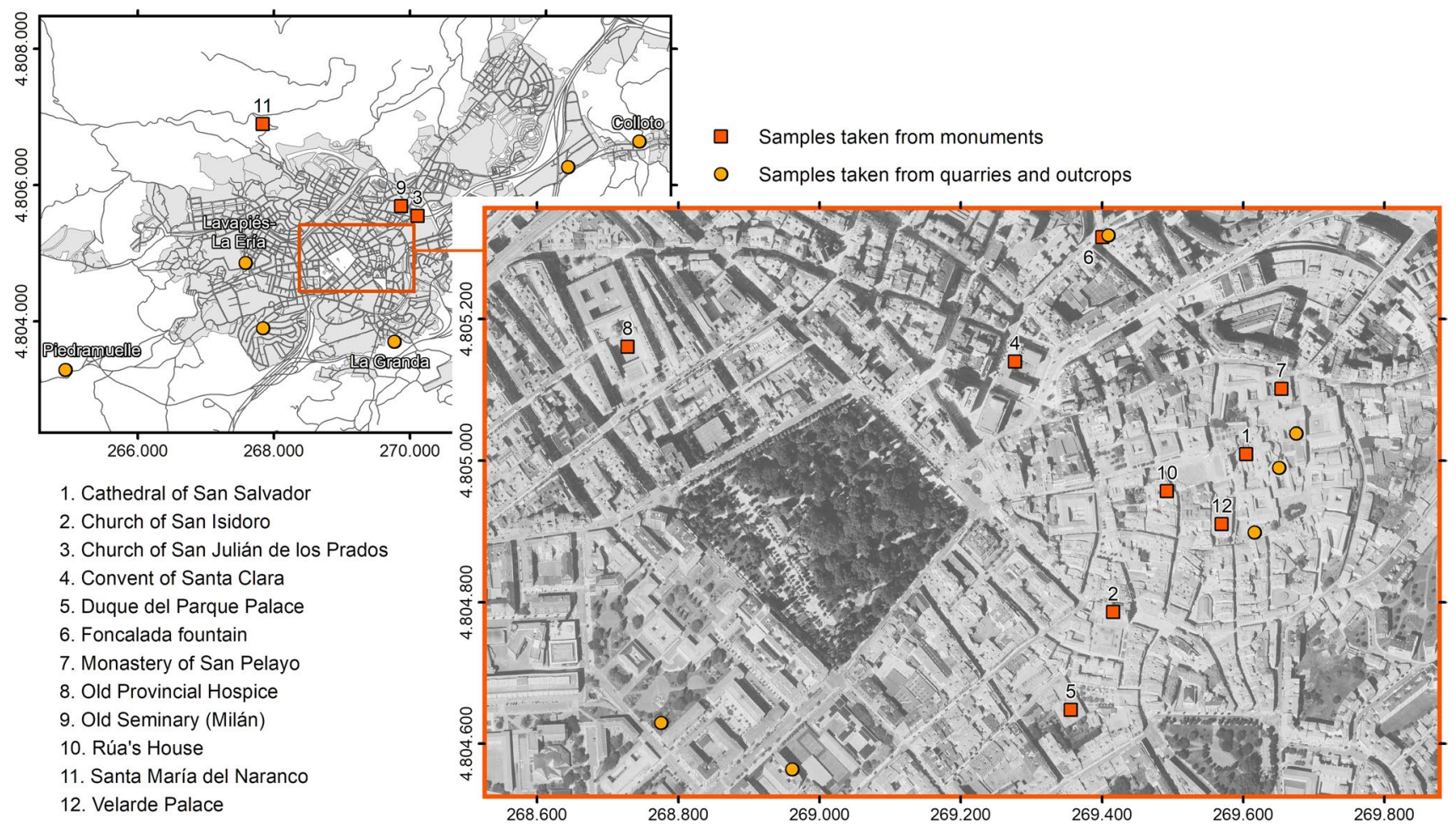

Fig. 4 Location of sampling sites. The map includes monuments, quarries, and other outcrops

Table 1 Monuments with thin section specimens from architectural elements

\begin{tabular}{llll}
\hline Monuments & Building date & Architectural style & $\begin{array}{l}\text { Samples } \\
\text { number }\end{array}$ \\
\hline Church of San Julián de los Prados** & IX cent. & Pre-Romanesque & 4 \\
Santa María del Naranco** & IX cent. & Pre-Romanesque & 8 \\
Foncalada fountain** & IX cent & Pre-Romanesque & 1 \\
Cathedral of San Salvador* & XIII-XVIII cent. & Gothic & 29 \\
Rúa's House & XV cent. & Gothic & 1 \\
Church of San Isidoro* & XVII (1646-81) & Baroque & 1 \\
Monastery of San Pelayo (vicarage) & XVIII $(1703-4)$ & Baroque & 11 \\
Duque del Parque Palace & XVIII (1725-30) & Baroque & 2 \\
Old Provincial Hospice* & XVIII (1752) & Baroque & 2 \\
Convent of Santa Clara* & XVIII (1750-53) & Baroque & 6 \\
Palacio de Velarde Palace* & XVIII (1765) & Baroque & 1 \\
Old Seminary (Milán) & XIX (1895) & Neogothic & 1 \\
\hline
\end{tabular}

**World Heritage Sites, *Objects of Cultural Interest (BIC). 
Table 2 Points of the urban nucleus and its surroundings with outcrop

\begin{tabular}{ll}
\hline Outcrop & $\begin{array}{l}\text { Samples } \\
\text { number }\end{array}$ \\
\hline Cathedral: basement in the pilgrims' courtyard* & 9 \\
$\begin{array}{l}\text { Archeological Museum (San Vicente Monastery): base- } \\
\text { ment* }\end{array}$ & 5 \\
Corrada del obispo: next to the archiepiscopal palace* & 1 \\
Foncalada fountain: basement* & 4 \\
Auditorium area (old quarries of Fresno)* & 4 \\
Llamaquique area (old quarries of Fresno)* & 2 \\
Eria-Lavapiés (quarry area)** & 10 \\
Montecerrau (large roundabout)** & 5 \\
Colloto (under the church of Sta. Eulalia)** & 5 \\
Polygon of the Espíritu Santo (near Colloto)** & 5 \\
La Granda (quarries)** & 4 \\
Piedramuelle (quarries)** & 3 \\
\hline
\end{tabular}

*Urban nucleus in Fig. 4, ** Surrounding in Fig. 3 and 4

to the areas that possibly hosted exploitation fronts (Figs. 3 and 4).

In the laboratory, hand samples were studied macroscopically with the aid of a binocular microscope (Zeiss, Scope A1, AXIO). Appearance, color (Munsell 1905), roughness, porosity, degree of coherence, homogeneity, and structures were the main factors considered. Thin sections, without staining, prepared from the hand samples, were examined by means of petrographic microscopy, and varieties within each lithotype were identified according to the composition, texture, and porosity.

To calculate the grain size, the microscope has been calibrated with a micrometer and considered the most frequent size. The following European standards have been considered: UNE-EN 16085 (2014) in taking samples, UNE-EN
12407 (2007) in petrographic analysis, and UNE-EN 1936 (2007) to determine porosity. Rock classification was based on the limestone classification proposed by Folk (1962) and Dunham (1962).

Available historical documentation was also reviewed to verify and complete, if necessary, the source of stone for the most relevant constructions. When there was no written record of the supply area or quarry, this study was based on the construction chronology and the type of stone.

\section{Petrographic Characteristics: Lithotypes}

The varieties of Upper Cretaceous limestone used in the monuments of Oviedo can be distinguished visually by their color, granulometry, and degree of coherence or alteration behavior. The color can vary from light yellow to reddish, including different shades of ocher or medium beige. The texture is essentially granular, varying in grain size from very coarse $(2 \mathrm{~mm})$ to very fine (60 $\mu \mathrm{m})$. However, two lithotypes prevail: (i) one of medium to coarse grain size, coherent texture, and usually massive and homogeneous appearance and (ii) another one of very fine grain size that, in general, is less coherent and often banded. According to the historical data collected from different publications about the extraction of stone for monuments (De Caso 1981; Esbert et al. 1982; Esbert and Marcos 1983; Pastor Criado 1987; Alonso et al. 1999b; Gutiérrez-Claverol et al. 2012), and also in accordance with the petrographic characteristics of the materials, two main rock types or lithotypes can be easily distinguished: Piedramuelle (Fig. 2A, B, C and 5A) and La Granda (Figs. 2D, E, F and 5B).

Much less frequently, other limestone types have also been found in specific architectural elements of monuments
Fig. 5 Appearance of the two Cretaceous limestone lithotypes used in the monuments of Oviedo. A Oviedo Cathedral: the front corresponds to a facade with Piedramuelle stone; in the background, the chapel of the Rey Casto can be seen with La Granda stone. B Church of Santa María La Real de la Corte: the upper ashlars are made of Piedramuelle stone and the lower one of La Granda stone
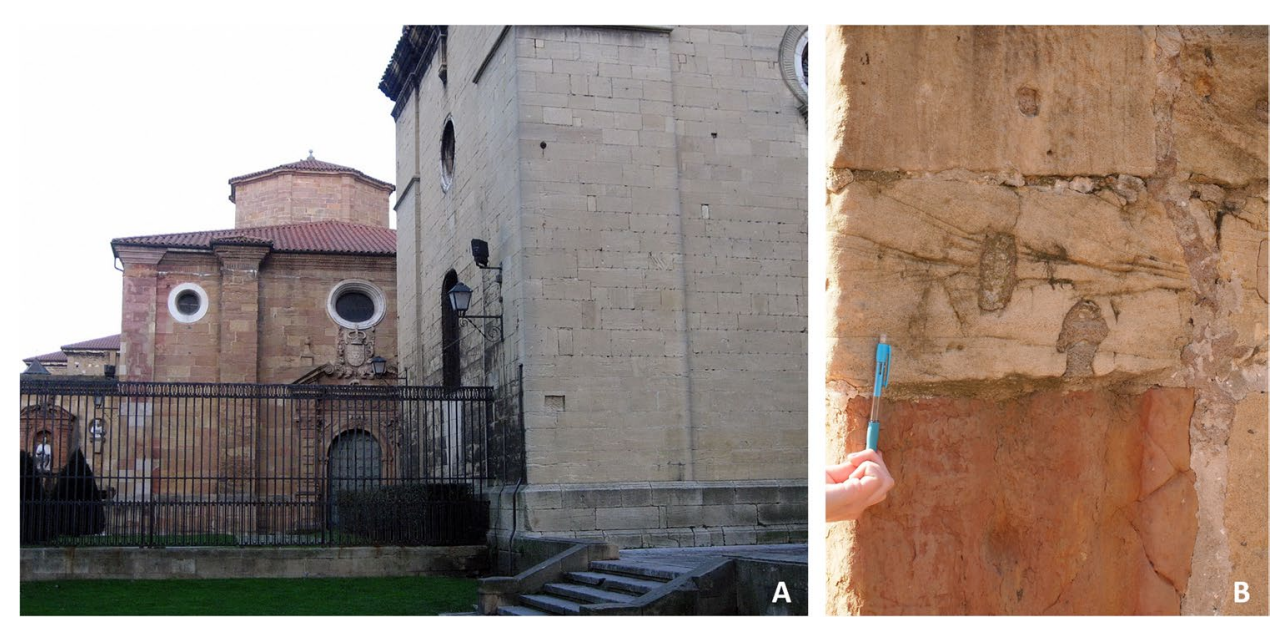
(shields, flooring...). These types also correspond to the Upper Cretaceous rocks found in the area.

\section{Piedramuelle Stone}

This stone is a sandy bioclastic limestone with a light color, yellowish tonality (10YR 8/3) and granular appearance. It is generally homogeneous and isotropic (Alonso et al. 1999a) although, in monuments, some ashlars may show diffuse banded or crossed stratification. Among the different samples of the study, collected both from monuments and outcrops, differences were observed in the nature, abundance and size of carbonate and siliciclastic grains, and in the characteristics of cement and porosity (Fig. 6). The analysis of these variations made it possible to establish several petrographic subtypes or varieties, the common and specific characteristics of which are detailed below.

The predominant mineral is calcite, and the siliciclastic content varies from 3 to $30 \%$. Quartz is the main component; smaller amounts of feldspars and rock fragments (finegrained sandstones and siltstones) are present, and muscovite and tourmaline are considered accessories. The texture is granular clastic, the carbonate grains are mostly peloids and bioclasts, with abundant mollusk and crinoid valves. The grain size of siliciclastic grains is similar or slightly smaller than the size of carbonate grains, and both are well classified and rounded. Cementation can be either partial, with small spatic calcite crystals arranged in a border around the grains (isopachous cement), or complete with spar druse mosaic, syntaxial, or poikilitic cement. In general, porosity is high (around 20\%) and pores are intergranular. The dominance of moldic pores indicates processes of calcite dissolution that can still remain active today. Pore size is relatively large, and pore communication is good, which facilitates the circulation of water, favors drying, and delays rock degradation.

The most significant variations in the studied samples are the grain size (medium or coarse), the siliciclastic content (low or high), the degree of cementation (partial or complete), and the porosity (number and type of pores). According to these characteristics, the microscopic analysis reveals five subtypes or varieties within Piedramuelle (Table 3): P-I, P-II, P-III, and P-IV.

\section{La Granda Stone}

This stone type is an impure limestone (has non-carbonated minerals) of very fine grain size and reddish or beige colors. It has a massive, banded, or slightly nodular appearance; muscovite and, sometimes, whitish calcite micro-geodes can often be observed. It is easily differentiated from
Piedramuelle due to its more intense tones and its extremely fine grain size (Fig. 7). This grain size gives the rock a fine texture, more suitable for carving, but it is also associated with the presence of fine siliciclastic minerals that make the rock more susceptible to weathering (Jiménez-González et al. 2008; Gutiérrez et al. 2012). More advanced weathering is another distinguishing feature of this rock type, easily perceived in monuments and historical constructions (Esbert et al. 1992b; Esbert et al. 1997).

Regarding mineralogy, calcite is the main component, and siliciclastic grains (mostly quartz, muscovite and altered glauconite) of very fine size $(60-100 \mu \mathrm{m})$ are abundant (10-20\%). Tourmaline, opaque (oxides of iron), and clay minerals are accessories. During diagenesis, carbonate grains, possibly small bioclasts and peloids, cemented by spatic calcite, frequently underwent important transformations, especially recrystallization, dolomitization, and dedolomitization processes. Because of these processes and the small grain size, the porosity is much lower (5\%), and pores are smaller. These processes also affected the color of the rock and make it possible to distinguish two subtypes or varieties (Table 4): red variety (G-I) and beige variety (G-II).

\section{Other Types of Limestones}

Other rock types also appear occasionally in the monuments (for example in Santa María del Naranco, the Old Provincial Hospice or the San Julián de los Prados church), but these are usually limited to specific architectural elements. These rocks range from crystalline limestones and dolomites to micritic limestones with a variable content of fossil remains and have undergone recrystallization, dolomitization, and de-dolomite processes to varying degrees (Fig. 8). As a result, their texture can be homogeneous, either micritic or crystalline, or heterogeneous, with micritic and crystalline zones in net contact with each other, and always with very low porosity. Considering the mentioned petrographic characteristics, three petrographic varieties have been distinguished (Table 5): OI, O-II, and O-III which are present in various levels of the Upper Cretaceous formations of Oviedo and its surroundings.

\section{Stratigraphic Location}

Considering the petrographic characteristics of the samples, the geology of the area, and the historical documentation, two formations can be established as possible sources of building materials for the monuments: the San Lázaro Formation and the Oviedo Formation, the only Cretaceous calcareous units that outcrop in the urban area (Fig. 9). 


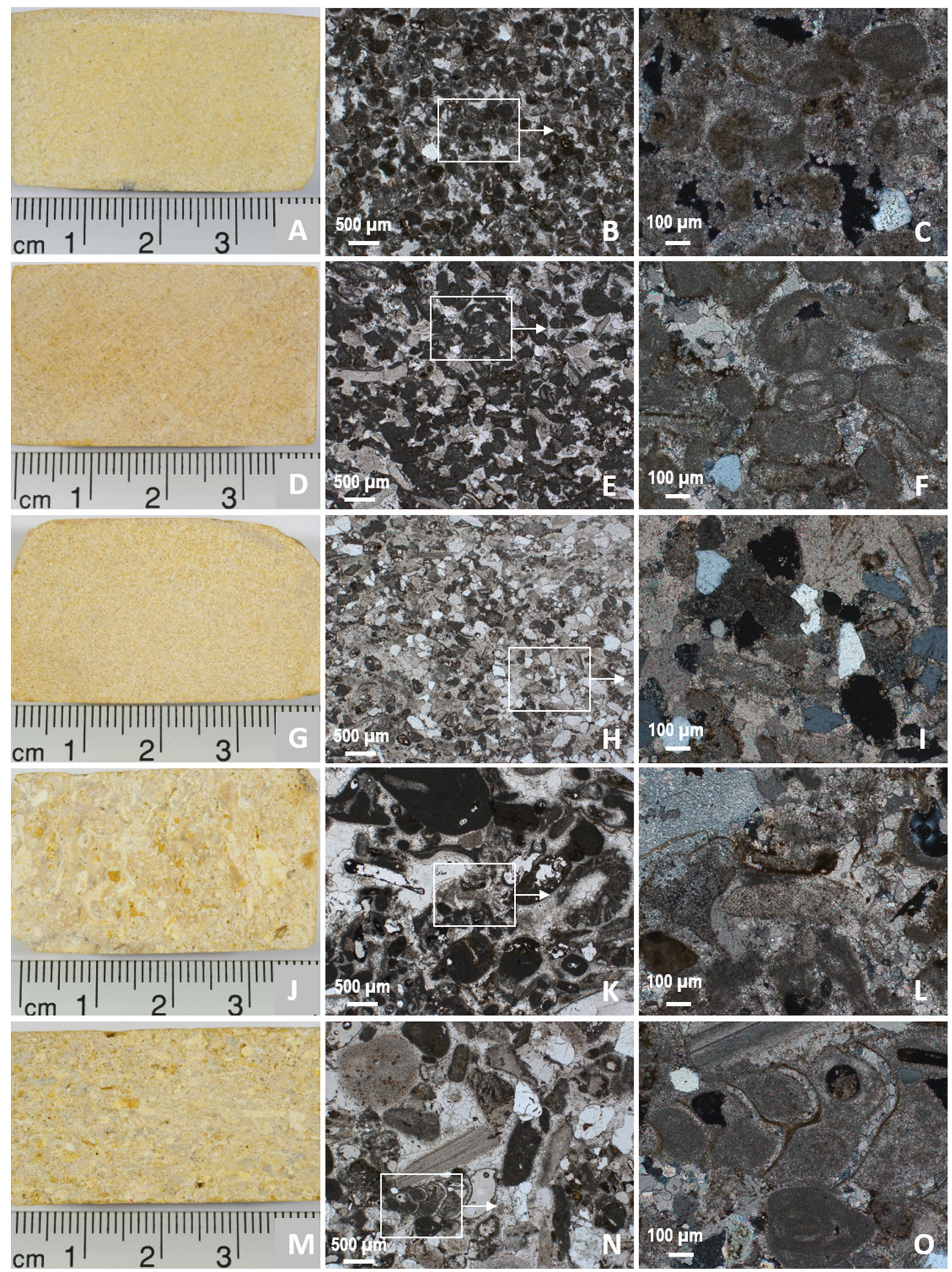


4Fig. 6 Piedramuelle stone, macroscopic and microscopic images of the different varieties: P-I (A, B, C), P-II $(\mathbf{D}, \mathbf{E}, \mathbf{F})$, P-III $(\mathbf{G}, \mathbf{H}, \mathbf{I})$, $\mathrm{P}-\mathrm{IV}(\mathbf{J}, \mathbf{K}, \mathbf{L})$ and P-V $(\mathbf{M}, \mathbf{N}, \mathbf{O})$ where the variations in grain size and petrographic components can be observed. Samples P-I, P-III, and P-V come from the cathedral, sample P-II from palace of Duque del Parque, and sample P-IV from the tower of San Pelayo Monastery. The photomicrographs were taken at the same scale and under the same conditions: general aspect $(\times 25 \mathrm{PL})$ and detail of the sample $(100 \mathrm{XN})$

The analyzed samples revealed that the same type of stone (i.e., rocks with similar petrographic features) can come from different stratigraphic levels. Thus, as shown in Fig. 10, some of the varieties of the two identified lithotypes, Piedramuelle, and La Granda appear both in the San Lázaro and the Oviedo Formations. This is possible as both formations were deposited in marine-littoral environments that oscillated between shallow platform (Fm. San Lázaro) and tidal plain (Fm. Oviedo) and, thus, facies with common features evolved in both.

The San Lázaro Formation outcrops around the urban nucleus of Oviedo, mainly in the northwestern area of the city and towards the southeast, where the stratotype was established (González-Fernández et al. 2004). In this formation, the varieties P-II, P-IV, and P-V of the Piedramuelle lithotype and varieties G-I and G-II of La Granda have been identified, together with the O-II of other types of limestone (Fig. 10).

Numerous quarries that supplied stone to the great buildings of the city are documented in this formation (Fig. 3). The most important ones were Santa Marina de Piedramuelle, La Granda, and Ayones (Gutiérrez-Claverol et al. 2012), located very close to the city of Oviedo. The first two of these quarries gave name to the lithotypes. In addition, during the sixteenth and eighteenth centuries, stone from this formation was extracted in other places near Oviedo, such as Colloto or La Manjoya, and in the twentieth century in Tiñana (about $4 \mathrm{~km}$ southeast of Oviedo) for restoration works of the cathedral tower.

The Santa Marina de Piedramuelle quarry was very active from the end of the fourteenth century to the middle of the sixteenth century. This quarry provided the large amount of stone used in the exterior fabric of the cathedral. The La Granda quarry operated from the end of the sixteenth century to the nineteenth century, and its rocks were widely used in the eighteenth century in monuments such as the cathedral (chapel of the Rey Casto, façade of the cloister), churches (San Isidoro), palaces (Valdecarzana), and convents (Santa Clara). The Ayones quarry started production in the middle of the seventeenth century and was closed in the middle of the eighteenth century. The stone extracted here was used to repair the cathedral tower and other buildings (City Hall) of that time.

The Oviedo Formation underlies most of the present city area, which also includes the hillock in which the initial urban nucleus was located. The varieties found in this formation are the P-I, P-II, P-III, and P-V of the Piedramuelle lithotype; the G-I and G-II of the La Granda lithotype; and the O-I, O-II, and O-III of other types of limestone (Fig. 10).

Although the strata that outcrop in the original urban nucleus do not seem to be thick enough to supply large blocks, such as those used in ashlars, they are undoubtedly

Table 3 Petrographic features of the different varieties of the Piedramuelle stone

\begin{tabular}{|c|c|c|c|c|}
\hline Variety & Classification (Folk) texture & Siliciclasts & Cementation & Porosity \\
\hline P-I(Fig. 6A, B, C) & $\begin{array}{l}\text { Biopelsparite. } \\
\text { Medium grain }(300-500 \mu \mathrm{m}) \text {. } \\
\text { Very well calibrated grains. }\end{array}$ & $5 \%$ & Partial isopachous & $\begin{array}{l}20 \% \\
\text { Intergranular and moldic }\end{array}$ \\
\hline P-II(Fig. 6D, E, F) & $\begin{array}{l}\text { Pelsparite. } \\
\text { Medium grain }(300-500 \mu \mathrm{m}) \text {. } \\
\text { More crystalline appearance. }\end{array}$ & $5 \%$ & $\begin{array}{l}\text { Complete spar } \\
\text { drusy mosaic }\end{array}$ & $\begin{array}{l}5 \% \\
\text { Moldic }\end{array}$ \\
\hline P-III(Fig. 6G, H, I) & $\begin{array}{l}\text { Biopelsparite. } \\
\text { Coarse grain }(300-500 \mu \mathrm{m}) \text {. } \\
\text { Poorly calibrated and more packed } \\
\text { grains. }\end{array}$ & $15-25 \%$ & $\begin{array}{l}\text { Variable spar drusy mosaic, and syn- } \\
\text { taxial }\end{array}$ & $\begin{array}{l}15 \% \\
\text { Moldic and intergranular }\end{array}$ \\
\hline P-IV(Fig. 6J, K, L) & $\begin{array}{l}\text { Biosparite } \\
\text { Coarse grain }(500-800 \mu \mathrm{m}) \text {. } \\
\text { Poorly calibrated grains and with some } \\
\text { intraclasts. }\end{array}$ & $3-5 \%$ & $\begin{array}{l}\text { Variable isopachous, spar drusy, and } \\
\text { syntaxial }\end{array}$ & $\begin{array}{l}15-20 \% \\
\text { Moldic and intergranular }\end{array}$ \\
\hline P-V(Fig. 6M, N, O) & $\begin{array}{l}\text { Biosparite. } \\
\text { Coarse grain }(500-800 \mu \mathrm{m}) \\
\text { Poorly rounded and more packed fossil } \\
\text { remains. }\end{array}$ & $15-30 \%$ & $\begin{array}{l}\text { Variable isopachous, spar drusy, and } \\
\text { syntaxial }\end{array}$ & $\begin{array}{l}10-20 \% \\
\text { Moldic and intergranular }\end{array}$ \\
\hline
\end{tabular}



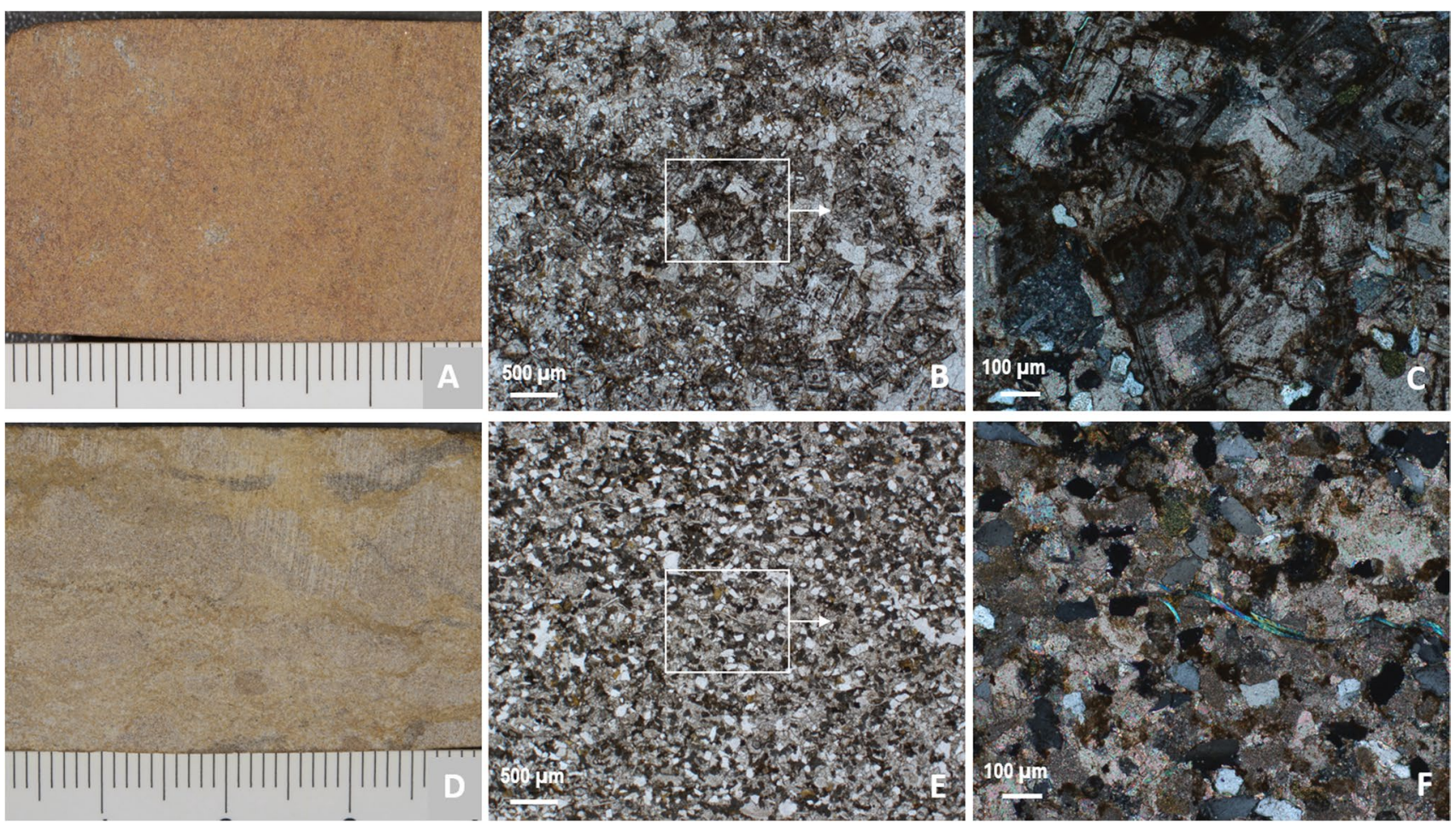

Fig. 7 La Granda stone, macroscopic and microscopic aspect of the two varieties: G-I (A, B, C) of more crystalline appearance and G-II (D, E, F) of more granular texture. Sample G-I come from the facade of San Pelayo Monastery and sample G-II were obtained from the

the source of the small ashlars encountered in the oldest constructions. Recent excavations carried out within the area of that initial urban nucleus (i.e., the construction site of the new building of the Museum of Fine Arts) yielded signs and remains of exploitation of these thin layers that are attributed, at least, to the twelfth-thirteenth centuries (Estrada 2014). However, the typical granular and porous ashlars, such as those observed on the facade of the cathedral, come from areas farther away from the urban nucleus, as revealed by historical documents (De Caso 1981).

The main quarries of this formation were those of Lavapiés, active since the beginning of the fifteenth century, and the already mentioned La Granda (Fig. 3), but some twenty exploitation points of much lower importance and intermittent chronology were also located in areas close to the urban nucleus (Gutiérrez-Claverol et al. 2012), areas that today belong to the city center. The most active period of the Lavapiés quarry was the seventeenth century, during which the best quality stone of the Piedramuelle lithotype was extracted for the baroque chapels and the upper cloister of the cathedral, baroque palaces, and convents. The most active period of the quarry of La Granda was the eighteenth century. In this outcrop, a fault places the San Lázaro and Oviedo Formations in contact; therefore, rocks from both cathedral. The photomicrographs were taken at the same scale and under the same conditions: general aspect $(\times 25 \mathrm{PL})$ and detail of the sample (100 XN)

formations were extracted. This mixture can be seen in different churches and palaces of that period.

The quarries that supplied rocks of the Oviedo Formation for the pre-Romanesque monuments Santa María del Naranco and San Miguel de Lillo should also be mentioned due to the historical interest of these buildings. These quarries, hardly visible today due to vegetation cover, are located near the mentioned monuments (Gutiérrez-Claverol et al. 2012). As shown in Fig. 3, the Oviedo Formation outcrops in that area due to an inverse fault, the Naranco Fault, which places the Paleozoic on top of the Cretaceous, and the Cretaceous on top of the Paleogene.

In the period of greatest activity, extraction in the quarries was carried out manually, as the use of blasting was not widespread. The procedure involved (GutiérrezClaverol et al. 2012): (i) clearing and removal of the overburden (i.e., altered rock and soils); (ii) delimitation of the blocks, conditioned by the thickness of the strata (subhorizontal) and the subvertical fractures; (iii) introduction of metal or wooden wedges to separate the blocks, preferably within bedding plans and joints; (iv) extraction of the blocks with the help of iron bars; and (v) first roughing of the pieces. Working was staggered, starting at the top of the rock face, and forming as many benches as there were strata or groups of strata. In some cases, the extraction was 
Table 4 Petrographic characteristics of the varieties of La Granda stone

\begin{tabular}{llll}
\hline Variety & Color & Appearance & Texture \\
\hline G-I (Fig. 7A, B, C) & Red 10R 5/6 & $\begin{array}{r}\text { Massive, with large } \\
\text { crystalline nuclei. }\end{array}$ & Heterogranular lens, dedolomite-type, with poikilotopic areas \\
G-II (Fig. 7D, E, F) & Beige 5YR 7/4 & $\begin{array}{r}\text { Banded, with some } \\
\text { crystalline nuclei. }\end{array}$ & $\begin{array}{l}\text { Recrystallized bioclastic, without signs of dolomitization, } \\
\text { with poikilotopic areas }\end{array}$ \\
\hline
\end{tabular}
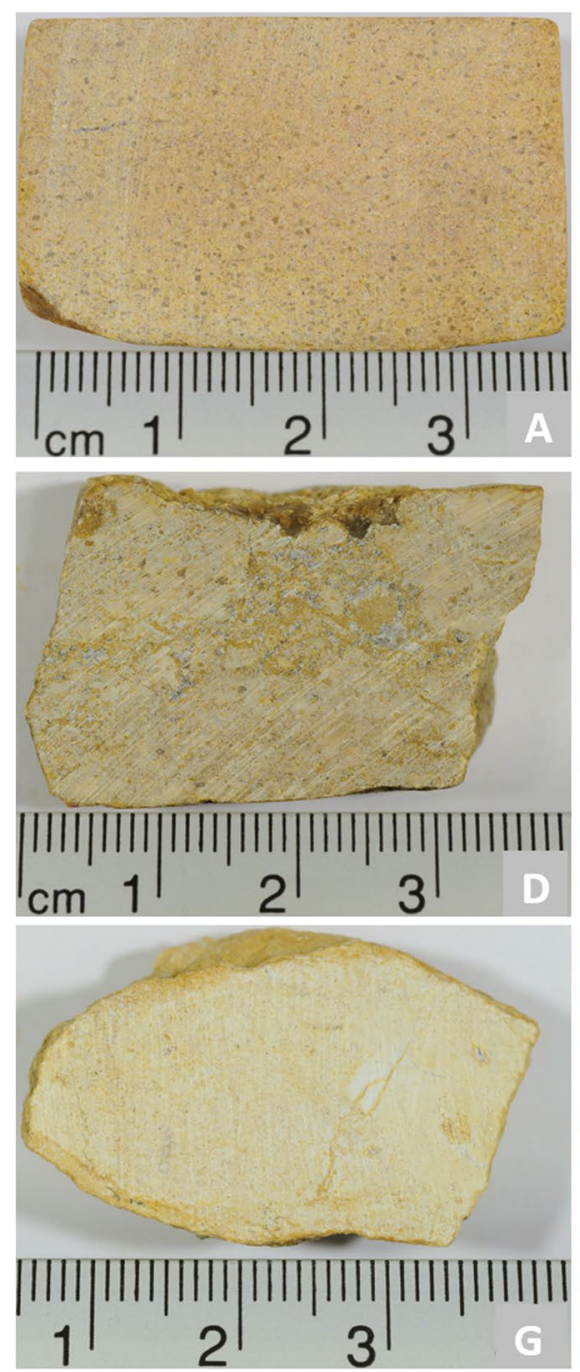
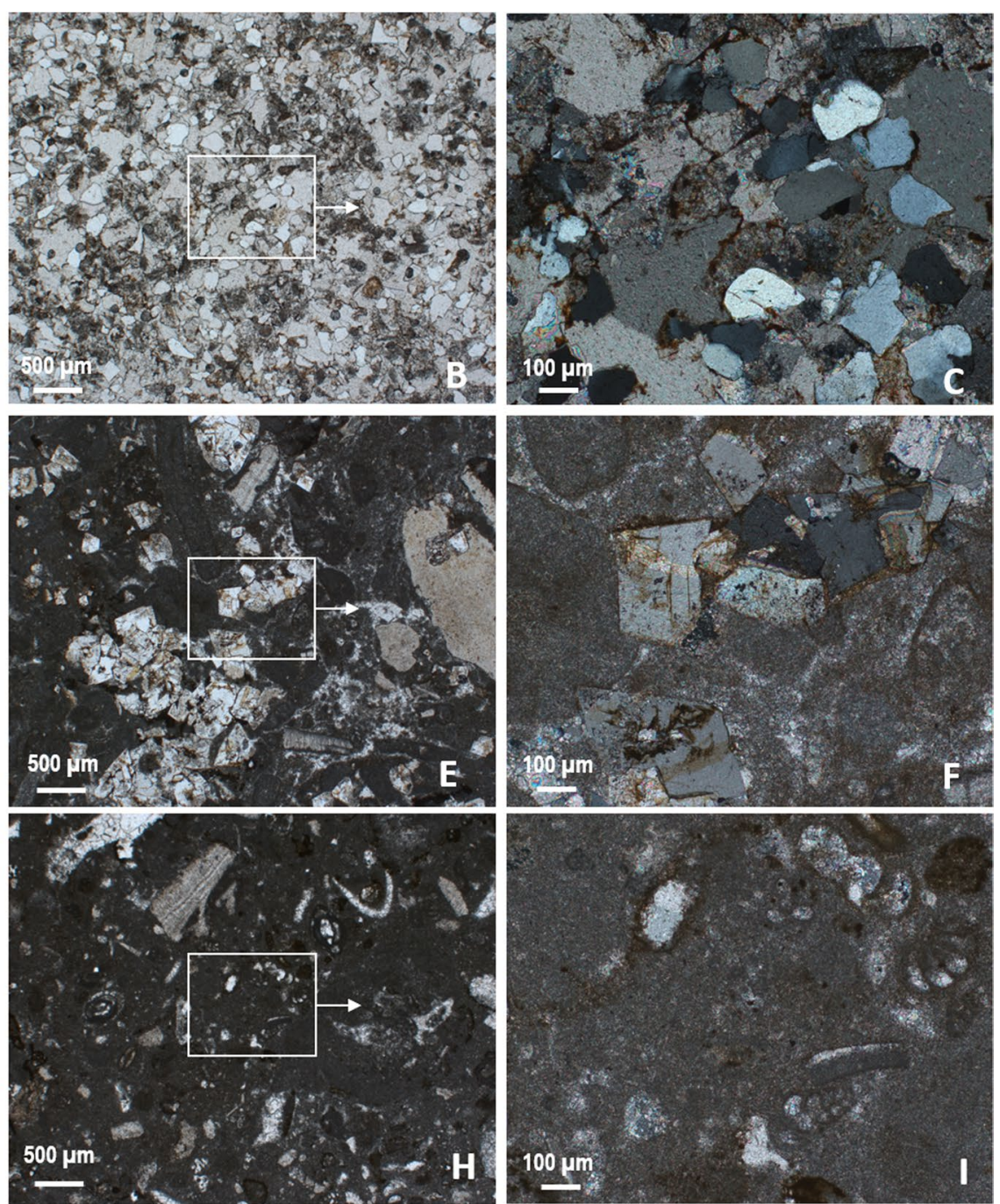

Fig. 8 Other types of Cretaceous limestones: O-I (A, B, C) crystalline limestone with abundant quartz grains, O-II (D, E, F) micritic limestones with crystalline zones and O-III $(\mathbf{G}, \mathbf{H}, \mathbf{I})$ wackestone-type micritic limestone. Sample O-I come from the strata located under the Colloto church, and there are similar ones in the Cathedral Cloister and in Sta. María del Naranco. Sample O-II is from an old shield

carried out well in advance of the building work (even 2 years), in order to expose the stone blocks to the elements and thus discard those most susceptible to weathering for use in façades. of the Old Provincial Hospice. Sample O-III is from inside the San Julián de los Prados church in the grains that form the flooring. The photomicrographs were taken at the same scale and under the same conditions: general aspect $(\times 25$ PL) and detail of the sample (100 $\mathrm{XN}$ )

\section{Presence in Monuments and Historical Analysis}

The analysis of the samples taken from monuments (Fig. 4, Table 1) also allowed us to study the presence of 
Table 5 Petrographic characteristics of other types of Cretaceous limestones

\begin{tabular}{|c|c|c|c|c|}
\hline Variety & Color & Appearance & Siliciclasts & Texture \\
\hline O-I(Fig. 8A, B, C) & Beige-yellow 7,5YR 8/3 & $\begin{array}{l}\text { Crystalline, with diffuse and } \\
\text { scattered grains }\end{array}$ & $\begin{array}{l}20-30 \% \\
200-600 \mu \mathrm{m} \\
\text { calibrated and } \\
\text { rounded }\end{array}$ & $\begin{array}{l}\text { Crystalline, often poikilotopic. } \\
\text { Originally a sandy biopel- } \\
\text { sparite that underwent recrys- } \\
\text { tallization, dolomitization, and } \\
\text { mainly dedolomitization }\end{array}$ \\
\hline O-II(Fig. 8D, E, F) & $\begin{array}{l}\text { Reddish 10R } 5 / 6+\text { beige } 7,5 \mathrm{YR} \\
8 / 3\end{array}$ & $\begin{array}{l}\text { Coarse mottling, often hetero- } \\
\text { geneous }\end{array}$ & $\begin{array}{l}1-5 \% \\
60-100 \mu \mathrm{m}\end{array}$ & $\begin{array}{l}\text { Crystalline + biomicrite. } \\
\text { Originally a micritic limestone } \\
\text { that underwent partial or local } \\
\text { recrystallization, dolomitiza- } \\
\text { tion, and mainly dedolomiti- } \\
\text { zation }\end{array}$ \\
\hline O-III(Fig. 8G, H, I) & Beige-gray 10YR 7/1 & $\begin{array}{l}\text { Massive, with crystalline veins } \\
\text { and cores }\end{array}$ & $\begin{array}{l}1-5 \% \\
100-150 \mu \mathrm{m}\end{array}$ & $\begin{array}{l}\text { Biomicrite, wackestone. It } \\
\text { presents some foraminifera, } \\
\text { peloids, and sometimes large } \\
\text { fossil remains. Low degree of } \\
\text { recrystallization of the micrite }\end{array}$ \\
\hline
\end{tabular}

Fig. 9 Field appearance of the San Lázaro Formation in the old Santa Marina de Piedramuelle quarry (A and $\mathbf{B})$ and the Oviedo Formations in the old Lavapiés quarry (C and $\mathbf{D})$. See location in Fig. 3
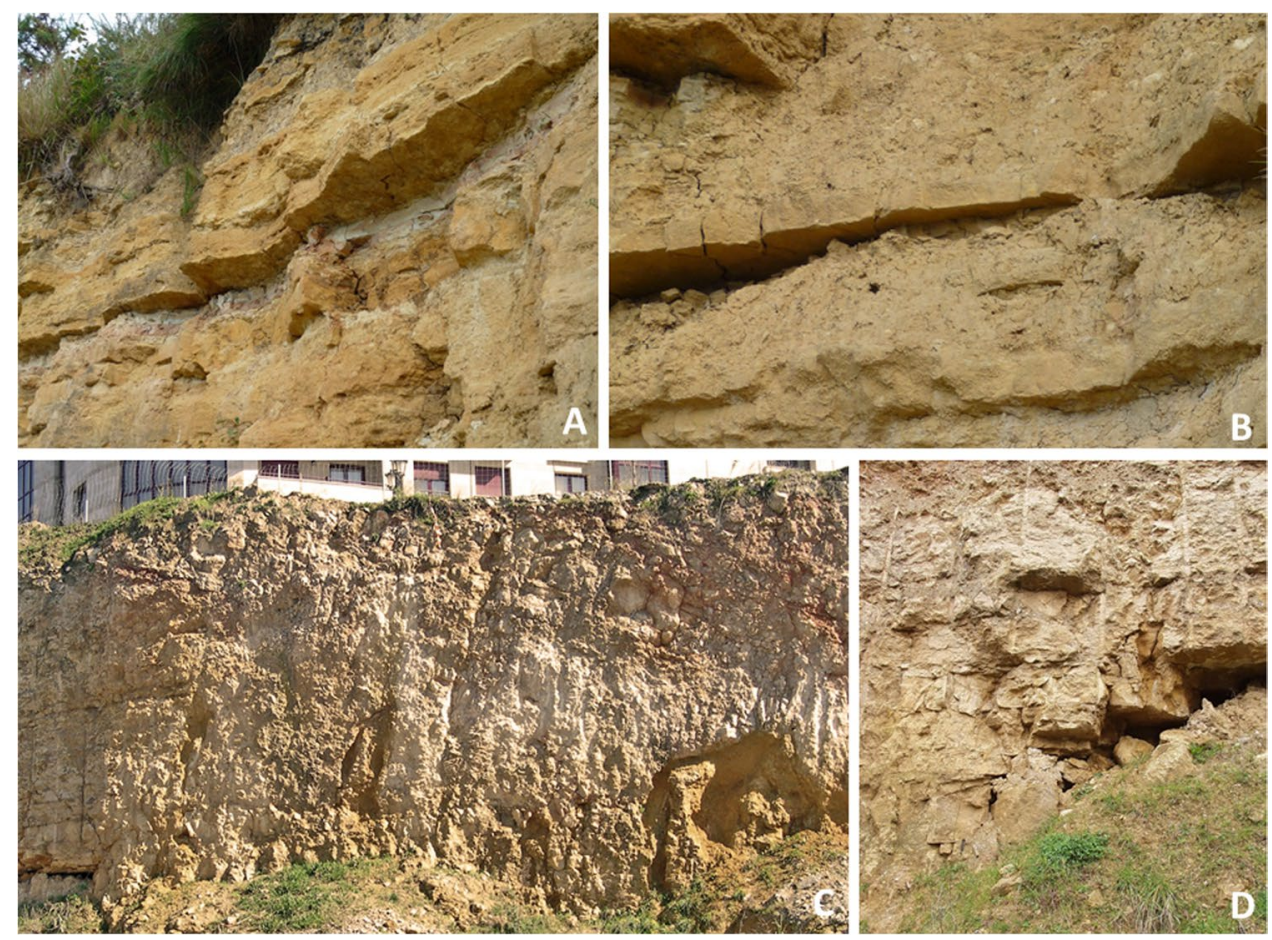

the different lithotypes and varieties in the most representative monuments of Oviedo. Piedramuelle is the dominant building stone, representing around $70 \%$, versus the $30 \%$ of La Granda. P-I, P-IV, and P-V are the most common varieties of the Piedramuelle lithotype; while G-1 prevails among the La Granda varieties. The varieties O-I, O-II, and O-III appear occasionally in monuments but are not part of their fabric.

The analysis of the historical documentation revealed that the evolution of use of a given stone type may depend both on geological aspects, and on external factors. Geological characteristics can influence the way in which a stone is extracted, its quality, and the thickness of the obtained ashlars, which is limited by the thickness of the strata. The alternation of different types of stone used in the same building is also frequent because the petrographic characteristics influence the aptitude of each type of rock for a specific use or for a specific architectural element. External factors are, for example, proximity and therefore the required transport, or contractual aspects in relation to ground ownership.

Likewise, the review of historical documents provided data about how the use of different stone types evolved in time. Thus, Piedramuelle is known to be the most relevant 
Fig. 10 Location of the different varieties of Cretaceous stones in the stratigraphic column of the Asturian Cretaceous

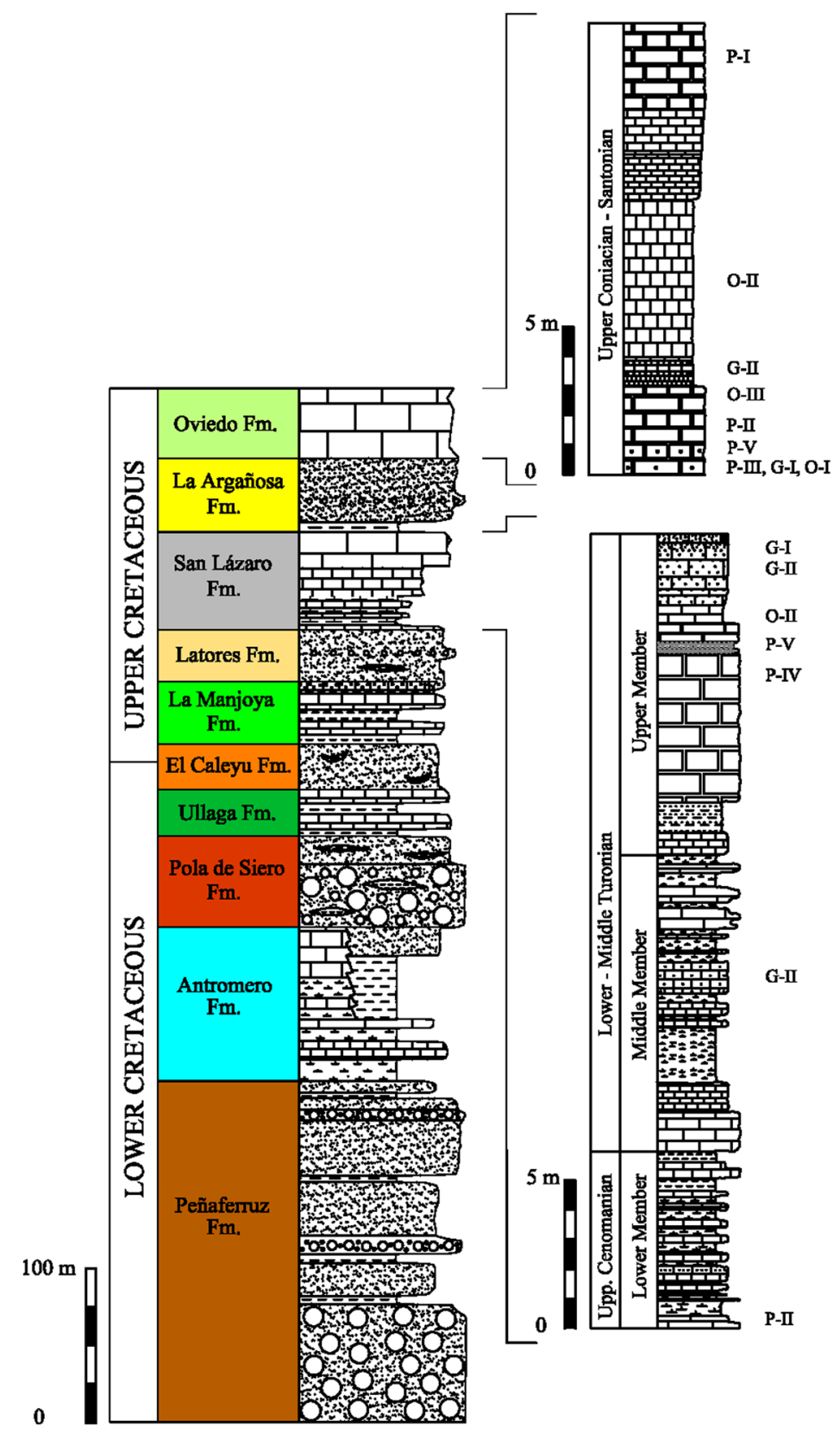

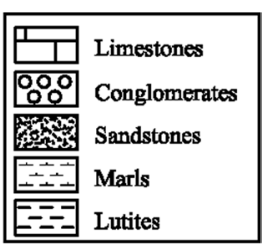

lithotype in monumental Oviedo from the days of the first constructions. La Granda appears in monumental buildings mainly from the seventeenth century, and it was the most frequent dimension stone during the eighteenth century. This lithotype can also be found in older constructions but only because of modern restoration works (e.g., the Foncalada fountain or Santa María del Naranco).

The relative amount of different lithotypes and varieties, as well as the evolution of their use over time, is consistent with the stratigraphic origin and the distribution of outcrops of the San Lázaro and Oviedo Formations. Piedramuelle appears in the upper and the lower parts of both formations, while La Granda dominates in the San Lázaro Formation and only appears in the basal part of the Oviedo Formation (Table 6). This may justify why Piedramuelle has been the most widely used lithotype since ancient times, given that the Oviedo Formation outcrops more frequently in the center of the city and in its closest surroundings, particularly in the Lavapiés quarry.

The proximity of the quarries to the monuments was another decisive factor, as frequently verified by researchers (Caballero Zoreda and Utrero Agudo 2005; Palacio-Prieto 2015; Bonomo et al. 2019) and evidenced in the oldest buildings in Oviedo, such as Santa María del Naranco or San Miguel de Lillo, which quarries were located within a radius of less than $500 \mathrm{~m}$. 
Table 6 Lithotypes, varieties and stratigraphic affiliation of the Cretaceous limestones identified in the monuments

\begin{tabular}{|c|c|c|c|}
\hline Lithotype & Variety & Formation & Monuments \\
\hline \multirow[t]{13}{*}{ Piedramuelle } & P-I & Oviedo (upper part) & Santa María del Naranco \\
\hline & & & Cathedral (very abundant: facade). \\
\hline & P-II & Oviedo (lower part) & Duque del Parque Palace (facade) \\
\hline & & San Lázaro (lower member) & \\
\hline & P-III & Oviedo (lower part) & Santa María del Naranco. \\
\hline & & & Cathedral (abundant) \\
\hline & P-IV & San Lázaro (upper member) & Santa María del Naranco \\
\hline & & & Cathedral, (very abundant: upper cloister) \\
\hline & & & Monastery of San Pelayo (church tower). \\
\hline & & & Palace Velarde (facade) \\
\hline & & & Old Seminary or Milán building (socle). \\
\hline & $\mathbf{P}-\mathbf{V}$ & Oviedo (lower part) & Cathedral (abundant: arc) \\
\hline & & San Lázaro (upper member) & Monastery of San Pelayo (romanic arches) \\
\hline \multirow[t]{4}{*}{ La Granda } & G-I & Oviedo (lower part) & Cathedral (cloister facade), Monastery of San Pelayo (vicarage), \\
\hline & & San Lázaro (upper member) & $\begin{array}{l}\text { Church of San Isidoro, Old convent of Santa Clara, Old Provincial } \\
\text { Hospice, Columns Rúa's House and Palaces, Ashlars replaced in the } \\
\text { Foncalada fountain }\end{array}$ \\
\hline & G-II & Oviedo (lower part) & Monastery of San Pelayo (vicarage) \\
\hline & & San Lázaro (middle and upper member) & Old convent of Santa Clara \\
\hline \multirow{4}{*}{$\begin{array}{l}\text { Other Creta- } \\
\text { ceous lime- } \\
\text { stones }\end{array}$} & O-I & Oviedo (lower part) & Santa María del Naranco \\
\hline & O-II & Oviedo (middle part) & Old Provincial Hospice (shield) \\
\hline & & San Lázaro (upper member) & Old convent of Santa Clara \\
\hline & O-III & Oviedo (lower part) & San Julián de los Prados church (inside) \\
\hline
\end{tabular}

The largest exploitation sites were those of the San Lázaro Formation located in a rural environment but less than $5 \mathrm{~km}$ from the urban center. This implied a relatively short transport of the material, as was usual at the time. The quarries of the Oviedo Formation were much smaller and were closer to the urban nucleus. All of them were abandoned more than a century ago, and today, most can only be identified due to anomalous topographic features. This is because, given the climate of the region, the vegetation covers the outcrops, and old quarry fronts cannot be seen. However, there are still well-visible remains of some of them, such as in Piedramuelle and Lavapiés.

\section{Conclusions}

Upper Cretaceous limestones are the traditional and most abundant building stones in the monuments of Oviedo. They can be grouped into two major lithotypes, called Piedramuelle and La Granda, which visually can be easily distinguished by their color and granulometry. In more detail and considering their petrographic characteristics (mainly siliciclastic content, degree of cementation, and porosity), five varieties of Piedramuelle and two varieties of La Granda can be recognized. Exceptionally, other types of Cretaceous limestones also appear in specific architectural elements that cannot be included into these lithotypes. They were classified as a third group called "other types."

Piedramuelle is a biosparite to biospelsparite type limestone that is characterized by its light yellowish tones, granular texture, and generally high porosity. La Granda is a very fine-grained limestone, rich in siliciclastic grains, and shows reddish and beige tones. Its very low porosity is due to recrystallization, dolomitization, and dedolomitization processes.

All of the studied limestones come from the San Lázaro and Oviedo Formations (Upper Cretaceous), formations that outcrop in the city of Oviedo and its surroundings, which confirms that the use of stone was conditioned by its availability in the proximity of the buildings. The comparative petrographic analysis of samples from monuments, outcrops and boreholes, revealed that some varieties of both lithotypes (P-II, P-V, G-I and G-II) appear repeatedly at different stratigraphic levels and are present in both formations.

Regarding the presence of the two main lithotypes in ashlars or masonry of the monuments, the estimated percentage of use is $70 \%$ for Piedramuelle and $30 \%$ for La Granda. Piedramuelle already appears in the oldest buildings from the ninth century, and it was the most frequent stone building material until the seventeenth century, while the use of La Granda started at the end of the sixteenth century and became very common in the seventeenth and eighteenth 
centuries. This is in accordance with the assumption that the Oviedo Formation supplied more building material since ancient times due to its closer proximity to the monuments.

Knowledge of local stones (their properties and their provenance) is important for the restoration of monuments and other buildings in urban centers. In addition, these stones give the buildings their own identity and define the urban landscape of the city.

On the other hand, the use of local stones can contribute to environmental sustainability and is an objective of current EU policy. In this sense, it would be recommended that local authorities promote regulations for the recovery of materials from buildings in ruins so that they can be used for future rehabilitation or restoration tasks. In Oviedo, the massive use of Cretaceous rocks in the most important monuments of the city makes them an essential material in future restoration and rehabilitation works. Therefore, the characteristics and behavior of these lithologies and their different varieties must be known and their value as a natural stone of the monumental heritage should be recognized and disseminated.

Acknowledgements We express our gratitude to Manuel GutiérrezClaverol and Eduardo Menéndez-Casares for their help in the fieldwork and to the company GEA aseoría geológica for some samples and related information. Likewise, we thank Tímea Kovács for reviewing the manuscript.

Funding Open Access funding provided thanks to the CRUE-CSIC agreement with Springer Nature.

\section{Declarations}

Competing interests The authors declare no competing interests.

Open Access This article is licensed under a Creative Commons Attribution 4.0 International License, which permits use, sharing, adaptation, distribution and reproduction in any medium or format, as long as you give appropriate credit to the original author(s) and the source, provide a link to the Creative Commons licence, and indicate if changes were made. The images or other third party material in this article are included in the article's Creative Commons licence, unless indicated otherwise in a credit line to the material. If material is not included in the article's Creative Commons licence and your intended use is not permitted by statutory regulation or exceeds the permitted use, you will need to obtain permission directly from the copyright holder. To view a copy of this licence, visit http://creativecommons.org/licenses/by/4.0/.

\section{References}

Ajanaf T, Gómez-Gras D, Navarro A, Martín-Martín JD, Rosell JR, Maate A (2020) The building stone of the Roman city of Lixus (NW Morocco): provenance, petrography and petrophysical characterization. Geol Acta 18(13):1-16. https://doi.org/10.1344/ GeologicaActa2020.18.13

Alonso FJ, Ordaz J, Valdeón L, Rojo A, Díaz-Paché F, Esbert RM (1999a) Caracterización petrofísica de la caliza de Piedramuelle
(Oviedo, Asturias). Trab Geol 21:25-32. https://doi.org/10.17811/ tdg.21.1999.25-33

Alonso FJ, Ordaz J, Valdeón L, Rojo A, Díaz-Paché F, Esbert RM (1999b) Petrophysical characterization of the Piedramuelle limestone (Oviedo, Asturias). Geology Papers 21:25-32. https://doi. org/10.17811/tdg.21.1999.25-33

Alonso FJ, Esbert RM, Ordaz J, Valdeón L, Rojo A, Mateos F (2007) El claustro de la catedral de Oviedo: conservación de la piedra. In: In: Ciencia, tecnología y sociedad para una conservación sostenible del patrimonio pétreo. Restauradores sin fronteras y CSICUCM, Madrid, pp 13-21

Álvarez S, Esbert RM, Díaz-Paché F, Alonso FJ, Ordaz J, Súarez del Río LM, Rodríguez Rey A, Ruiz de Arganoña VG (2004) San Julián de los Prados: Agresiones, estado actual y propuestas para la conservación de un monumento singular del Prerrománico asturiano. Restauración Rehabil 85:52-57

Anania L, Badal A, Barone G, Belfiore CM, Calabrò C, La Russa MF, Mazzoleni P, Pezzino A (2012) The stones in monumental masonry buildings of the "Val di Noto" area: new data on the relationships between petrographic characters and physical-mechanical properties. Constr Build Mater 33:122-132. https://doi.org/10. 1016/j.conbuildmat.2011.12.076

Barroso CE, Oliveira DV, Ramos LF (2020) Physical and mechanical characterization of vernacular dry stone heritage materials: schist and granite from Northwest Portugal. Constr Build Mater 259:1-21. https://doi.org/10.1016/j.conbuildmat.2020.119705

Bone DA (2016) Historic building stones and their distribution in the churches and chapels of West Sussex, England. Proc Geol Assoc 127(1):53-77. https://doi.org/10.1016/j.pgeola.2016.02.001

Bonomo AE, Acito AM, Prosser G, Rizzo G, Munnecke A, Koch R, Bentivenga M (2019) Matera's old quarries: geological and historical archives that need protection and valorization. Geoheritage 11:1603-1619. https://doi.org/10.1007/s12371-019-00413-x

Bugini R, Folli L (2008) Stones used in Milan architecture. Mater Constr 58(289-90):33-50

Caballero Zoreda L, Utrero Agudo MA (2005) Una aproximación a las técnicas constructivas de la Alta Edad Media en la Península Ibérica. Entre visigodos y omeyas. Arqueología de la Arquitectura 4:169-192

Carter EJ, Andrews E, Andrew K (2017) The provenance, petrology and sedimentology of building stone in Bromyard, Herefordshire, UK. Proc Geol Assoc 128:480-499. https://doi.org/10.1016/j. pgeola.2016.11.007

Corbí H, Martínez-Martínez J, Martin-Rojas I (2019) Linking geological and architectural heritage in a singular geosite: Nueva Tabarca Island (SE Spain). Geoheritage 11:703-716. https://doi.org/10. 1007/s12371-018-0327-7

Damas Mollá L, Uriarte JA, Aranburu A, Bodego A, Balciscueta U, García Garmilla F, Antigüedad I, Morales T (2018) Systematic alteration survey and stone provenance for restoring heritage buildings: Punta Begoña Galleries (Basque-Country, Spain). Eng Geol 247:12-26. https://doi.org/10.1016/j.enggeo.2018.10.009

De Caso F (1981). La Construcción de la Catedral de Oviedo. Tesis doctoral, Departamento de Historia Medieval, Universidad de Oviedo 515 p.

De Kock T, De Boever W, Dewanckele J, Boone MA, Jacobs P, Cnudde V (2015) Characterization, performance and replacement stone compatibility of building stone in the 12th century tower of Dudzele (Belgium). Eng Geol 184:43-51. https://doi.org/10.1016/j. enggeo.2014.10.026

De Kock T, Turmel A, Fronteau G, Cnudde V (2017) Rock fabric heterogeneity and its influence on the petrophysical properties of a building limestone: lede stone (Belgium) as an example. Eng Geol 216:31-41. https://doi.org/10.1016/j.enggeo.2016.11.007

Dino GA, Mehta N, Rossetti P, Ajmone-Marsan F, De Luca DA (2018) Sustainable approach towards extractive waste management: two 
case studies from Italy. Res Policy 59:33-43. https://doi.org/10. 1016/j.resourpol.2018.07.009

Dreesen R, Dusar M (2004) Historical building stones in the province of Limburg (NE Belgium): role of petrography in provenance and durability assessment. Mater Charact 53:273-287

Dunham RJ (1962) Classification of carbonate rocks according to depositional texture. In: W. E. Ham (Ed.). Classification of Carbonate Rocks. Am Assoc Petrol Geol Mem 1:108-121

Durante A, Rivers E, Beane G, Chau R. (2018) Understanding the effect of architectural and environmental features on human behavior. In: Advances in usability and user experience, AHFE 2017 607:521-531. https://doi.org/10.1007/978-3-319-60492-3_ 49

Esbert RM, Marcos RM (1983) Las piedras de la catedral de Oviedo y su deterioración. Colegio Oficial de Aparejadores y Arquitectos técnicos de Asturias, Oviedo, p 143

Esbert RM, Marcos RM, Alonso FJ (1982) La deterioración de las piedras de la Catedral de Oviedo. $1^{\text {a }}$ Parte: Petrografía y porosidad características intrínsecas determinantes de la deterioración de sus rocas carbonatadas. Mater Constr 185:61-71

Esbert RM, García-Ramos JC, Nistal AM, Ordaz J, Valenzuela M, Alonso FJ, Suárez de Centi C (1992a) El proceso digital de imágenes aplicado a la conservación de la piedra monumental. Un ejemplo: Santa María del Naranco. Revista de Arqueología 139:7-11

Esbert RM, Ordaz J, Alonso FJ, Suárez del Río LM (1992b) Estudio diagnóstico del deterioro de las piedras de la fachada del antiguo Hospicio provincial de Oviedo. Con. Int. Rehabilitación del Patrimonio Arquitectónico y Edificación 123-126.

Esbert RM, Valdeón L, Díaz-Paché F, Ordaz J, Alonso FJ (1997) La fachada de la iglesia de San Isidoro de Oviedo: etapas de intervención y sugerencias para su conservación y limpieza. Loggia, Arquitectura Restauración 3:82-89. https://doi.org/10. 4995/loggia.1997.5724

Esbert RM, Rojo A, Alonso FJ, Mateos FJ, Ordaz J, Valdeón L (2004) La conservación de la piedra del claustro. In: In VV.AA. La restauración de la torre y el claustro de la catedral de Oviedo. Ediciones Nobel, Oviedo, pp 284-302

Esbert RM, Alonso FJ, Ordaz J (2008) La petrofísica en la interpretación del deterioro y la conservación de la piedra de edificación. Trab Geol 28:87-95

Estrada R (2014) Excavaciones arqueológicas en la ampliación del Museo de Bellas Artes de Asturias. En: Intervenciones en el patrimonio cultural asturiano, 2007-2014. Principado de Asturias 192-206.

Fernández-Álvarez P, Pando L (2019) Desarrollo de un modelo geológico 3D en el centro urbano de Oviedo (Asturias). Bol Geol Min 130:489-503

Fio KF, Maricic A (2020) Usage of the Natural Stones in the City of Zagreb (Croatia) and Its Geotouristical Aspect. Geoheritage 12(3):1-18. https://doi.org/10.1007/s12371-020-00488-x

Folk RL (1962) Spectral subdivision of limestone types. In: W. E. Ham (Ed.). Classification of Carbonate Rocks. Am Assoc Petrol Geol Mem 1:62-84

Forestieria G, Álvarez de Buergo M (2019) Petrophysical-mechanical behavior of Grisolia stone found in the architectural heritage of southern Italy. Mater Constr 69(334):1-12. https://doi.org/10. 3989/mc.2019.04118

Fort R, Álvarez del Buergo M, Pérez-Monserrat EM, Gómez-Heras M, Varas-Muriel MJ, Freire DM (2013) Evolution in the use of natural building stone in Madrid, Spain. Q J Eng Geol Hydrogeol 46:421-429. https://doi.org/10.1144/qjegh2012-041

Fronteau G, Moreau C, Thomachot-Schneider C, Barbin V (2010) Variability of some Lutetian building stones from the Paris Basin, from characterisation to conservation. Eng Geol 115(34):158-166. https://doi.org/10.1016/j.enggeo.2009.08.001
García-del-Cura MA, Benavente D, Martínez-Martínez J, Nora Cueto N (2012) Sedimentary structures and physical properties of travertine and carbonate tufa building stone. Constr Build Mater 28(1):456-467. https://doi.org/10.1016/j.conbuildmat.2011. 08.042

Gökçe MV, İnce I, Okuyucu C, Doğanay O, Fener M (2020) Ancient Isaura Quarries in and Around Zengibar Castle (Bozkır, Konya), Central Anatolia, Turkey. Geoheritage 12(69):1-10. https://doi. org/10.1007/s12371-020-00498-9

González-Fernández B, Menéndez-Casares E, Gutiérrez-Claverol M, García-Ramos JC (2004) Litoestratigrafía del sector occidental de la cuenca cretácica de Asturias. Trab Geol 24:43-80

González-Fernández B, Marcos-Pascual C, Menéndez-Casares E (2010) Hydrogeological and mineralogical analisis of the preromanesque monument of Santa María del Naranco Asturias, Spain. Geoarchaeology 25:497-513. https://doi.org/10.1002/ gea.20313

Gutiérrez J, Mas A, Gil E, Galvañ V (2012) Clay-related damage in rainscreen walls built with natural stone coverings. Constr Build Mater 29:357-367. https://doi.org/10.1016/j.conbuildmat.2011. 10.060

Gutiérrez-Claverol M, Torres M (1995) Geología de Oviedo. Descripción, recursos y aplicaciones. Ayuntamiento de Oviedo, Oviedo, p 276

Gutiérrez-Claverol M, Pando L, González-Fernández B (2004) Problemática de las calizas del Cretácico Superior en las cimentaciones de Oviedo. Geogaceta 36:99-102

Gutiérrez-Claverol M, Pando L, García-Ramos JC (2008) Procesos y productos de alteración de formaciones rocosas en Asturias y su repercusión-económica. Bol Geol Min 119:211-230

Gutiérrez-Claverol M, Luque C, Pando LA (2012) Canteras históricas de Oviedo. Aportación al patrimonio arquitectónico. Hércules, Oviedo $251 \mathrm{pp}$.

Jiménez-González I, Rodríguez-Navarro C, Scherer GW (2008) Role of clay minerals in the physicomechanical deterioration of sandstone. J Geophys Res 113:1-17. https://doi.org/10.1029/2007JF000845

Julivert M, Fontboté JM, Ribeiro A, Conde L (1972) Mapa tectónico de la Península Ibérica y Baleares. Instituto Geológico y Minero de España, Madrid, p 113

López-Plaza M, López-Moro FJ, Esparza-Arroyo A (2016) Procedencia del material granítico de los molinos de vaivén prehistóricos: el caso del yacimiento Cogotas I de Arroyo Mucientes-San Lázaro (Castronuño, Valladolid) y propuesta de una marcha metodológica general. Complutum 27(1):63-79. https://doi.org/10.5209/CMPL. 53217

Malfilatre C, Boulvais P, Dabard MP, Bourquin S, Hallot E, Pallix D, Gapais D (2012) Petrographical and geochemical characterization of Comblanchien limestone (Bourgogne, France): a fingerprint of the building stone provenance. Compt Rendus Geosci 344(1):1424. https://doi.org/10.1016/j.crte.2011.12.002

Mao Y, Jinda Q, Bao-Jie H (2020) Impact of the heritage building façade in small-scale public spaces on human activity: based on spatial analysis. Environ Impact Assess Rev 85:1-13. https://doi. org/10.1016/j.eiar.2020.106457

Martínez-Martínez J, Benavente D, Jiménez S, García-del-Cura MA, Ordóñez S (2017) Stone weathering under Mediterranean semiarid climate in the fortress of Nueva Tabarca island (Spain). Build Environ 121:262-276. https://doi.org/10.1016/j.buildenv.2017.05. 034

Martínez-Torres LM (2007) Lithological maps of churches in the Diocese of Vitoria (Spain): space-time distribution of building stones and ancient quarries. Build Environ 42(2):860-865. https://doi. org/10.1016/j.buildenv.2005.10.004

Mateos FJ, Valdeón L, Rojo A (2004) Piedras de construcción de la fuente prerrománica de Foncalada: tipos y origen. Trab Geol 24:107-118 
Merino E, Andonaegui P, Chapa T, Pereira JP (2020) Petrographic and geochemical study of the stone warrior stelae from Central Iberia: linking the geological record and archaeological heritage. Geoarchaeology 35:177-197. https://doi.org/10.1002/gea.21759

Munsell AH (1905) A color notation. G.H. Ellis Co., 86 pp.

Ordaz J, Alonso FJ, Esbert RM, Mateos FJ, Valdeón L, Rojo A (2004) La intervención en la piedra del claustro de la catedral de Oviedo. Menhir 16:72-85

Palacio-Prieto JL (2015) Geoheritage within cities: Urban Geosites in México City. Geoheritage 7:369-373. https://doi.org/10.1007/ s12371-014-0136-6

Pando L, Luque C, Gutiérrez-Claverol M (2011) La cantera de Lavapiés (Cretácico Superior) y su aportación al acervo arquitectónico de Oviedo. Trab Geol 31:60-76

Pastor Criado MI (1987). Arquitectura purista en Asturias. Consejería de Educación Cultura y Deportes, Principado de Asturias 286 p.

Pulgar JA, Alonso JL, Espina RG, Marín JA (1999) La deformación alpina en el basamento varisco de la Zona Cantábrica. Trab Geol 21:283-294

Rojo A, Esbert RM, Valdeón L, Alonso FJ, Mateos FJ, Ordaz J (2006) La conservación de la piedra del Claustro de la Catedral de Oviedo. Loggia, Arquitectura Restauración 19:96-107. https:// doi.org/10.4995/loggia.2006.3398

Shekofteh A, Oudbashi O, Cultrone G, Ansari M (2020) Geochemical and petrographic identification of stone quarries used for the construction of the Anahita Temple of Kangavar (West Iran). Heritage Sci 8(14):1-18. https://doi.org/10.1186/s40494-020-0361-z

Sitzia F, Lisci C, Mirão J (2021) Accelerate ageing on building stone materials by simulating daily, seasonal thermo-hygrometric conditions and solar radiation of Csa Mediterranean climate. Constr Build Mater 266(Part A):1-17. https://doi.org/10.1016/j.conbu ildmat.2020.121009
UNE-EN 12407 (2007). Natural stone test methods. Petrographic examination

UNE-EN 16085 (2014). Conservation of Cultural property. Methodology for sampling from materials of cultural property. General rules

UNE-EN 1936 (2007). Natural stone test methods. Determination of real density and apparent density, and of total and open porosity

Valdeón L (2004) La conservación de las fábricas de sillería de la torre gótica. En: La restauración de la torre y el claustro de la catedral de Oviedo, VV.AA. Ediciones Nobel, Oviedo 111-142.

Valdeón L, Esbert RM (2000) Seguimiento de los trabajos de conservación de la piedra. La fachada de la iglesia de San Isidoro de Oviedo. Loggia, Arquitectura Restauración 10:88-93. https://doi. org/10.4995/loggia.2000.5204

Valdeón L, Rojo A, Mateos FJ, Alonso FJ, Ordaz J, Esbert RM (2003) La limpieza con láser de la piedra del claustro de la Catedral de Oviedo. Restauración Rehabil 81:42-47

Vázquez P, Alonso FJ, Carrizo L, Molina E, Cultrone G, Blanco M, Zamora I (2013) Evaluation of the petrophysical properties of sedimentary building stones in order to establish quality criteria. Constr Build Mater 41:868-878. https://doi.org/10.1016/j.conbu ildmat.2012.12.026

Vázquez P, Sánchez-Delgado N, Carrizo L, Thomachot-Schneider C, Alonso FJ (2018) Statistical approach of the influence of petrography in mechanical properties and durability of granitic stones. Environ Earth Sci 77(287):1-17. https://doi.org/10.1007/ s12665-018-7475-6

Zoghlami K, Martín-Martín JD, Gómez-Gras D, Navarro A, Parcerisa D, Rosell JR (2017) The building stone of the Roman city of Dougga (Tunisia): provenance, petrophysical characterisation and durability. Compt Rendus Geosci 349(8):402-411. https://doi.org/ 10.1016/j.crte.2017.09.017 